\title{
JÓZEFA OBRĘBSKIEGO ETNOSOCJOLOGIA POLESIA W ŚWIETLE PYTAŃ O JEGO ŻYCIE I DZIELO. TYTULEM WPROWADZENIA
}

\author{
JÓZEF OBRĘBSKI'S ETHNOSOCIOLOGY \\ OF POLESIE IN LIGHT OF HIS LIFE AND WORK. \\ AS FOR INTRODUCTION
}

\begin{abstract}
The article provides comments to five articles constituting the cycle entitled "Józef Obrębski - Ethnosociology - Polesie then and now" and contextualises them in a bio-historical perspective. It presents an outline of Obrębski's scientific biography and reflects upon the causes of his absence in the mainstream history of anthropology and sociology. Although from the point of view of western principles of success Obrębski did not succeeded in his scientific career, he definitely was a remarkable actor of the scientific field. His takeaways and inspirations have started to influence this field not earlier than after his death. The articles included in the current cycle represent one of the examples of contemporary reception of Obrębski's outcome, generating a scientific discussion.
\end{abstract}

Key wo rds: Józef Obrębski; Polesie; history of anthropology

Streszczenie

Artykuł komentuje i kontekstualizuje teksty zamieszczone w cyklu "Józef Obrębski - Etnosocjologia - Polesie wczoraj i dziś". Przez przedstawienie zarysu drogi naukowej Obrębskiego i refleksję nad przyczynami nieobecności tego uczonego w kanonie historii antropologii i socjologii ustanawia wspólną dla całego cyklu perspektywę biograficzno-historyczną.

\section{JÓZEF OBRĘBSKI \\ ETNOSOCJOLOGIA POLESIE WCZORAJ I DZIŚ}

ANNA ENGELKING Instytut Slawistyki Polskiej Akademii Nauk, Warszawa E-mail: engelking@ispan.waw.pl http://orcid.org/0000-0003-3225-8084

CITATION: Engelking, A. (2019) Józefa Obrębskiego etnosocjologia Polesia w świetle pytań o jego życie i dzieło. Tytułem wprowadzenia. Sprawy Narodowościowe. Seria nowa, 2019(51). https://doi.org/10.11649/sn.2127

This work was supported by the author's own resources. No competing interests have been declared.

This is an Open Access article distributed under the terms of the Creative Commons Attribution 3.0 PL License (creativecommons.org/licenses/by/3.0/pl/), which permits redistribution, commercial and non-commercial, provided that the article is properly cited. (C) The Author(s) 2019

Publisher: Institute of Slavic Studies, Polish Academy of Sciences 


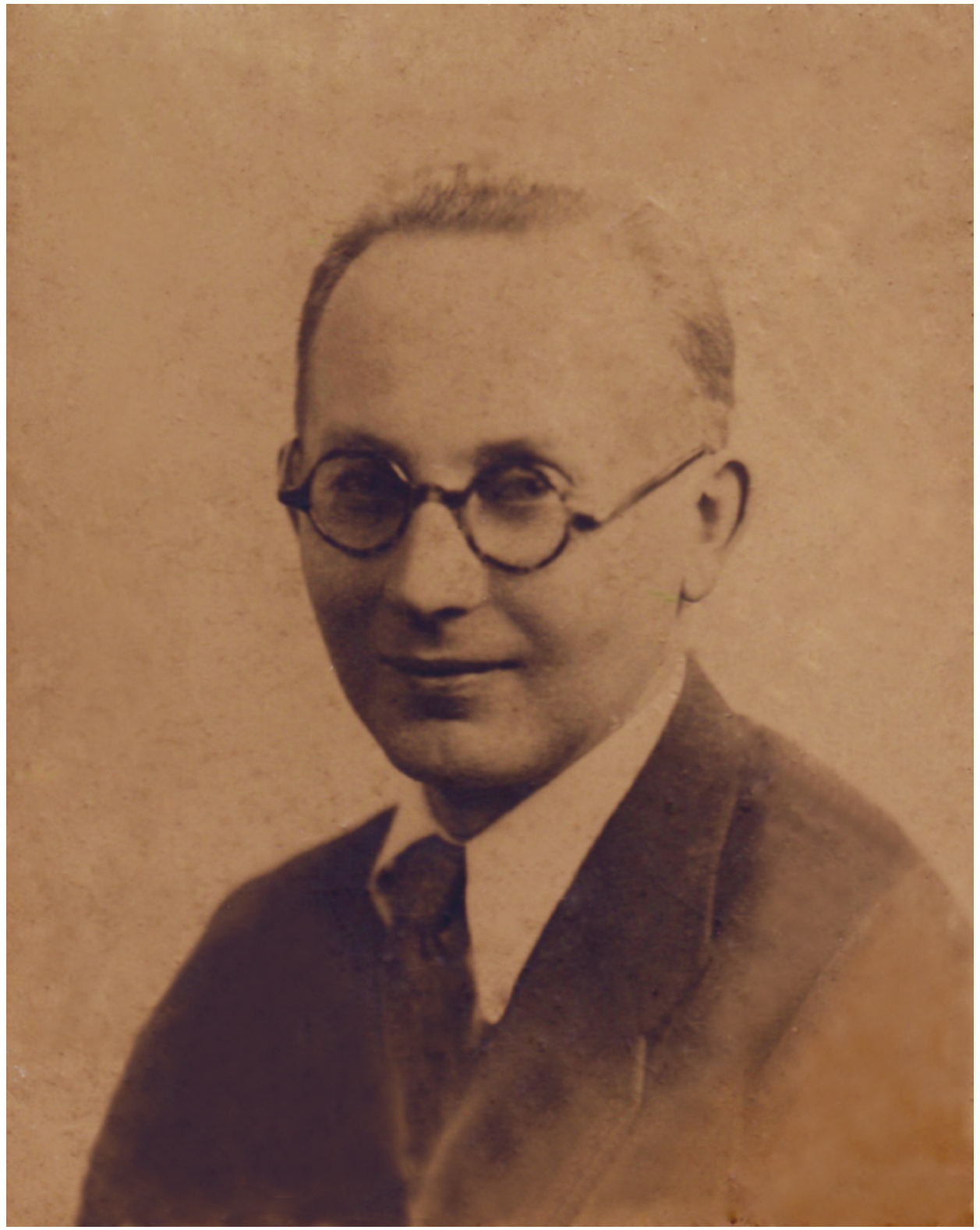

Józef Obrębski (1905-1967) w latach trzydziestych

Ze zbiorów Archiwum Uniwersytetu Warszawskiego (spuścizna Antoniny Obrębskiej-Jabłońskiej) 
Mimo że z punktu widzenia zachodnich kategorii sukcesu, Obrębski nie zrobił kariery naukowej, był wybitnym aktorem pola nauki. Jego ustalenia i inspiracje zaczęły wywierać wpływ na to pole dopiero po jego śmierci. Prezentowane teksty są jednym z przykładów współczesnej recepcji Obrębskiego, generującej naukową dyskusję.

Słowa kluczowe: Józef Obrębski; Polesie; historia antropologii

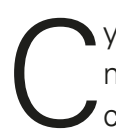
ykl pięciu artykułów komentujących i kontekstualizujących wybrane aspekty dokonań badawczych Józefa Obrębskiego, związanych z jego działalnością jako etnosocjologa-terenowca na Polesiu, nie po raz pierwszy łączy tego uczonego i „Sprawy Narodowościowe". Więcej, powiedzieć można, że cyklem tym kontynuujemy istniejącą już tradycję. Przypomnijmy, że właśnie to czasopismo opublikowało w 1936 roku dwa artykuły Obrębskiego współtworzące założycielską czwórcę tekstów prezentujących jego podejście do zagadnień etniczności i procesów narodotwórczych: Problem etniczny Polesia (Obrębski, 1936b)² oraz Statyczne i dynamiczne podejście w badaniach narodowościowych (Obrębski, 1936d)³. 70 lat później, w 2006 roku, ukazał się numer specjalny nowej już serii "Spraw Narodowościowych", zatytułowany W stulecie urodzin Józefa Obrebskiego. Oprócz opracowanych naukowo przedruków kilku jego zapomnianych artykułów i recenzji oraz serii tekstów polskich i zagranicznych autorów poświęconych biografii i dziełu uczonego ${ }^{4}$, zawiera on także pierwodruki trzech powojennych angielskich prac Obrębskiego wraz z polskimi przekładami (Obrębski, 2006b, 2006c, 2006d, 2006e, 2006f, 2006h).

Inspiracją do przygotowania niniejszego cyklu była pięćdziesiąta rocznica śmierci Józefa Obrębskiego. Zmarł on w wieku 62 lat, 28 grudnia 1967 roku w Nowym Jorku, pozostawiając ogromny, nieopublikowany dorobek naukowy - materiały z badań terenowych prowadzonych w różnych lokalizacjach oraz nieukończone opracowania. W roku 2017 upłynęła też dekada od ukazania się drukiem pierwszego tomu Studiów etnosocjologicznych Obrębskiego - serii pism uczonego opracowywanej na podstawie rozproszonych publikacji i ineditów ze spuścizny archiwalnej. Ten tom, Polesie (Obrębski, 2007g), odzwierciedla znany stosunkowo najlepiej obszar działalności naukowej Obrębskiego, cieszący się zainteresowaniem, co zrozumiałe, także wśród badaczy białoruskich i ukraińskich. Dlatego też sesję naukową z okazji 50-lecia śmierci Obrębskiego zorganizowano w Mińsku, w Instytucie Językoznawstwa im. Jakuba Kołasa Państwowej Akademii Nauk Białorusi ${ }^{5}$. Jej pokłosiem jest publikacja (Bahdanovich \& Svistunova, 2018) prezentująca wygłoszone wówczas referaty - są to wstępne, krótsze wersje czterech ${ }^{6}$ spośród pięciu artykułów wchodzących w skład niniejszego cyklu. Na jego użytek zostały one przepracowane i rozwinięte.

Pozostałe dwa (Obrębski, 1936a, 1936c) ukazały się w tym samym 1936 roku w „Przeglądzie Socjologicznym". Ich uzupełnione i opracowane naukowo przedruki zob. odpowiednio: Obrębski, 2007a, 2005b.

2 Tekst uzupełniony i opracowany naukowo jako: Obrębski, 2007d.

3 Opracowany naukowo przedruk w: Obrębski, 2005d.

4 Są wśród nich dwa artykuły ukazujące prace Obrębskiego o Polesiu z perspektywy etnografii białoruskiej (zob.: Alunina, 2006; Czarniakiewicz, 2006).

5 Dwuczęściowa sesja poświęcona Józefowi Obrębskiemu i jego siostrze Antoninie Obrębskiej-Jabłońskiej, założycielce polskiej białorutenistyki, odbyła się w ramach konferencji naukowej „Biełaruska-polskija mounyja, litaraturnyja i historyka-kulturnyja suwiazi" w Mińsku w dniach 21-23 czerwca 2018 r. Organizatorami konferencji byli: Hramadskaje abjadnannie „Miżnarodnaja asacyjacyja biełarusistau”, Fiłałahiczny fakultet Biełaruskaha dziarżaunaha uniwiersiteta, Instytut mowaznaustwa imia Jakuba Kołasa NAN Biełarusi oraz Instytut Polski w Mińsku.

6 Są to opublikowane po polsku artykuły: P. Cichorackiego, Józef Obrębski wobec społecznego i politycznego radykalizmu poleskiej wsi lat 30. Diagnozy i recepty, ss. 170-179; A. Engelking, Antropolog a polityka. Jesz- 
Niezależnie od tego, że życie i dzieło Józefa Obrębskiego było już przedmiotem kilku dziesiątków publikacji i że dotyczące go artykuły znajdują się w trzech renomowanych słownikach biograficznych (Armon, 1978; Engelking, 2007a; Wincławski, 2007), przypomnijmy tu pokrótce jego drogę naukową, traktując ją jako wspólną dla prezentowanego cyklu kontekstualizację biograficzno-historyczną.

Józef Obrębski urodził się 18 lutego 1905 roku w miejscowości Teplik na Podolu w rodzinie oficjalisty w majątku Potockich. Wczesne dzieciństwo spędził na ziemiach białoruskich i ukraińskich, mieszkając w kolejnych majątkach, i w Kijowie; około 1911 roku owdowiała matka, nauczycielka, zamieszkała z Józefem i jego dwiema starszymi siostrami w Warszawie. Obrębski uczęszczał do gimnazjum Emiliana Konopczyńskiego; maturę zdał w czerwcu 1924 roku w gimnazjum im. Sienkiewicza w Krakowie. Zaliczył dwa trymestry na Wydziale Prawa Uniwersytetu Warszawskiego, gdzie słuchał m.in. wykładu Leona Petrażyckiego z socjologii, zetknął się także z Ludwikiem Krzywickim. W 1925 roku rozpoczął studia w nowo utworzonym Studium Słowiańskim Uniwersytetu Jagiellońskiego. Był uczniem Kazimierza Moszyńskiego (w zakresie etnografii Słowian) i Kazimierza Nitscha (w zakresie filologii słowiańskiej). Od początku studiów aktywnie pracował naukowo jako asystent Moszyńskiego; brał udział (z profesorem i sam) w dwóch kilkumiesięcznych ekspedycjach naukowych na Bałkany (były to interdyscyplinarne ekspedycje samochodowe "Orbisu" pod kierunkiem profesora geografii Ludomira Sawickiego), gdzie badał przede wszystkim archaiczną kulturę materialną. Magisterium uzyskał w 1930 roku na podstawie cyklu artykutów Rolnictwo ludowe wschodniej części Pótwyspu Batkańskiego (Obrębski, 1929, 1930, 1931a, 1931b).

Następnie studiował antropologię społeczną u Bronisława Malinowskiego w London School of Economics, jako stypendysta Fundacji Rockefellera. Znalazł się w gronie najbliższych uczniów Malinowskiego, jako jego asystent badawczy m.in. przygotowywał kiriwiński materiał lingwistyczny do Coral Gardens and Their Magic. W latach 1932-1933 przez osiem miesięcy pracował w terenie w Macedonii, wśród górali Porecza (Engelking, 2018; Risteski, 2011). Były to pierwsze badania wsi europejskiej konsekwentnie przeprowadzone w paradygmacie funkcjonalizmu; wnioski z badań, które sformułował, można dziś uznać za prekursorskie m.in. w odniesieniu do studiów nad płcią kulturową. Zgromadził bogaty materiał etnograficzny (w tym ponad 500 fotografii) dotyczący m.in. organizacji społecznej, rodziny, systemu pokrewieństwa, magii i medycyny ludowej, wierzeń religijnych i obrzędowości. Zachowana dokumentacja terenowa i jej autorskie opracowania stanowią zawartość przygotowywanego obecnie do publikacji drugiego tomu Studiów etnosocjologicznych Obrębskiego - Macedonia (za życia uczonego drukiem ukazały się jedynie dwa artykuły) ${ }^{7}$.

W styczniu 1934 roku Obrębski uzyskał na Uniwersytecie Londyńskim doktorat z antropologii społecznej. Jego rozprawa doktorska, „Family Organization among Slavs as Reflected in the Custom of Couvade" (Organizacja rodzinna Stowian w świetle zwyczaju kuwady ${ }^{8}$ ), to oparte na materiale białoruskim i południowosłowiańskim studium patriarchalnej rodziny wiejskiej, którego punktem wyjścia jest analiza dekonstruująca mit o męż-

cze raz o Józefie Obrębskim, badaczu Polesia w II Rzeczypospolitej, ss. 187-202; M. Lubasia, Etnografia ideologii narodowych $i$ analiza procesów unaradawiania. Studia poleskie Józefa Obrębskiego z perspektywy czasu, ss. 158-170; oraz po białorusku S. Hruntowa, Jaurei i sacyjalnaja transfarmacyja na Palessi u pracach Juzefa Abrembskaha, ss. 180-186.

7 Dotyczyły one systemu magiczno-religijnego na Poreczu (zob. Obrębski, 1934, 1936e, 1936f, 1936g, 1936h, 1936i, 2006a, 2006g).

8 Maszynopis rozprawy znajduje się w archiwum London School of Economics. 
czyźnie w połogu, punktem dojścia zaś - wskazanie uwarunkowań społeczno-kulturowej dychotomii płci w badanych społecznościach.

Po powrocie do kraju Obrębski związał się poznańsko-warszawskim środowiskiem socjologicznym, współpracował z Florianem Znanieckim, Józefem Chałasińskim i Stanisławem Ossowskim. Wiosną 1934 roku rozpoczął dwuipółletnie badania terenowe na Polesiu, prowadzone od auspicjami Instytutu Badań Spraw Narodowościowych i Komisji Naukowych Badań Ziem Wschodnich (zob. Engelking, 2001, 2007b, 2019). Ekspedycja ta przyniosła obfite dane, dotyczące przede wszystkim zróżnicowania etnicznego Polesia, jego problematyki narodowościowej, sytuacji gospodarczo-społecznej i politycznej, tradycyjnej kultury ludowej oraz przemian modernizacyjnych w społecznościach wiejskich, a także bogatą dokumentację fotograficzną (około tysiąca negatywów). W 1936 roku Obrębski został wicedyrektorem Państwowego Instytutu Kultury Wsi, którym kierował Chałasiński. Prowadził tam i organizował badania nad emigracją wiejską, pamiętnikami chłopskimi i uniwersytetami ludowymi. Z ramienia PIKW kontynuował też prace na Polesiu. W kolejnym roku, 1937, kierował stacjonarną ekspedycją badawczą we wsi Olmany w powiecie stolińskim; jego zespół koncentrował się wówczas na badaniach nad młodzieżą i rodziną, w tym nad szkolnictwem wiejskim i biografiami rodzinnymi. Całość jego prac będących pokłosiem badań poleskich jest dostępna w tomie Polesie. Należący do spuścizny archiwalnej obszerny korpus materiałów terenowych zebranych przez uczestników ekspedycji pozostaje nieopracowany, choć jest dostępny dla badaczy 9 .

Okupację spędził Obrębski w Warszawie, angażując się w działalność konspiracyjną i akademicką (por. Nowakowski, 1992a). Wykładał socjologię i etnologię na tajnej Wolnej Wszechnicy Polskiej i tajnym Uniwersytecie Ziem Zachodnich; napisał dwie monografie dotyczące Polesia i jedną - macedońskiego Porecza. Po wyzwoleniu podjął prace w Wolnej Wszechnicy Polskiej w Łodzi, która wkrótce przekształciła się w Uniwersytet Łódzki. Objął tam katedre etnologii. W lutym 1946 roku habilitował się z etnologii na Uniwersytecie Warszawskim (na podstawie maszynopisu książki Polesie archaiczne). Pół roku później, zaproszony przez Edwarda Evans-Pritcharda, wyjechał na gościnne wykłady w Seminar on Social Anthropology do Oksfordu. Wykłady te, już po śmierci Obrębskiego, zostały opublikowane jako książka The Changing Peasantry of Eastern Europe (Obrębski, 1976).

W latach 1947-1948 Obrębski prowadził na Jamajce, z ramienia London School of Economics i British Colonial Social Science Research Council, badania nad strukturą i dynamiką rodziny, społeczno-ekonomicznymi aspektami lokalności oraz rodzącą się świadomością narodową (zob. Posern-Zieliński, 2006). Podobnie jak na Polesiu, interesowały go procesy przemian i zmiana kulturowa w kontekście modernizacji; podobnie gromadził też dokumenty osobiste. Z Jamajki pochodzi najbogatszy zbiór jego materiałów terenowych, których opracowanie do druku - choć znacznie zaawansowane - nie zostało ukończone. Wśród archiwaliów jamajskich znajdują się maszynopisy pięciu nieukończonych monografii. Opuszczając Jamajkę, Obrębski odrzucił propozycję kierowania katedrą socjologii na powstającej tam filii Uniwersytetu Londyńskiego. Zamierzał objąć katedrę etnologii na Uniwersytecie Warszawskim (którego pracownikiem pozostawał formalnie do 1950 r.). Ostatecznie jednak, wobec umacniania się w kraju stalinowskiego reżimu wraz z jego polityką dyskryminacji nauk społecznych (jak pisał do Znanieckiego: „Wybrałem etnologię jako przedmiot pozornie najbardziej oderwany. Niestety, pomyliłem się. Lenin i Stalin też byli etnologami"10), do działalności akademickiej w Polsce już nie powrócił.

9 Od niedawna znaczna część tych materiałów jest dostepna w postaci skanów w Archiwum Danych Jakościowych IFiS PAN.

10 W liście datowanym 3.05.1947 („Obrebski Collection”, Amherst, Mass). 


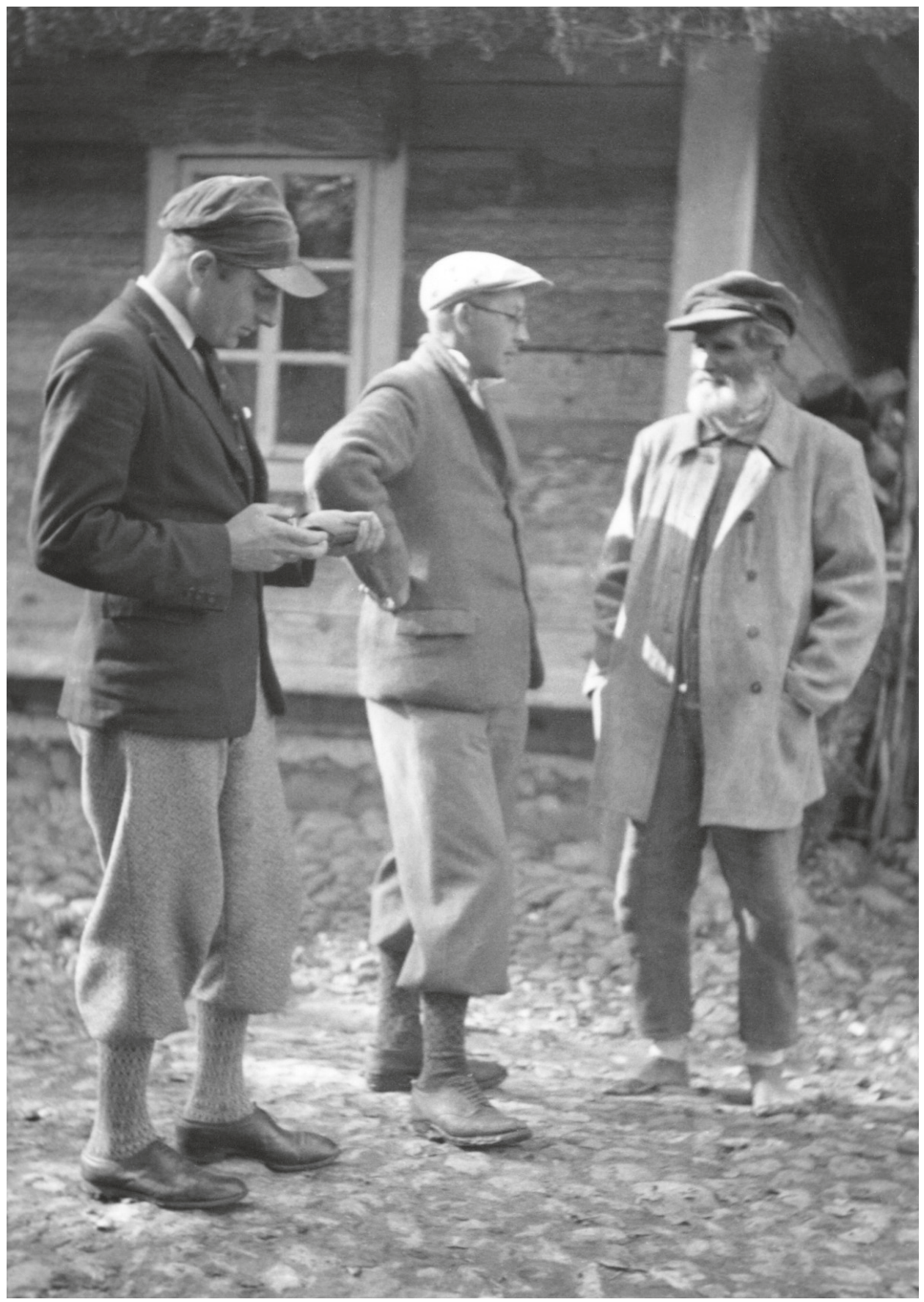

Józef Obrębski podczas badań terenowych we wsi Horyzdrycze jesienią 1934 roku. Obok Jan Teodorowicz i mieszkaniec wsi

Fot. Zygmunt Korybutiak

Ze zbiorów Archiwum University of Massachusetts w Amherst (Obrebski Collection) 
Na kolejną dekadę Obrębski związał się z Organizacją Narodów Zjednoczonych w Nowym Jorku. W okresie 1948-1958 pracowat w Departamencie Powierniczym ONZ jako specjalista od polityki społecznej, zagadnień rodziny, wychowania i edukacji, urbanizacji i procesów narodotwórczych. W latach następnych wykładał socjologię i antropologię w City University of New York i Long Island University; był pierwszym profesorem antropologii społecznej w tej uczelni.

W 1950 roku na I Międzynarodowym Kongresie Socjologicznym w Zurychu przedstawit referat "The Sociology of Rising Nations" (Obrębski, 1951)11 - teoretyczne podsumowanie badań macedońskich, poleskich i jamajskich. Był członkiem kilku amerykańskich towarzystw socjologicznych (także Polskiego Towarzystwa Socjologicznego), uczestniczył w konferencjach i seminariach. Wśród referatów i wykładów, które wygłosit, były: „Peasant Family in Jamaica" (na seminarium karaibskim w Uniwersytecie Columbia, 1957) ${ }^{12}$, "Social Background of the Polish Revolution of 1956" (na Wydziale Socjologii Queens College, 1958), "Rising Nations from an Anthropological Perspective” (na Wydziale Antropologii Uniwersytetu w Chicago, 1960) ${ }^{13}$, "Contemporary Marxist Sociology in Soviet Union and Poland" (na seminarium z teorii społecznej w Brooklyn College, 1961), "Social Structure and Ritual in a Macedonian Village" (na zjeździe American Anthropological Association w Filadelfii, 1961) $)^{14}$.

Po Październiku, w 1957 roku, Obrębski otrzymał propozycję objęcia katedry etnologii na Uniwersytecie Warszawskim. Projekt ten, podobnie jak późniejsze zabiegi Ossowskiego o gościnną profesurę dla niego w Zakładzie Socjologii UW, nie doczekał się realizacji. W roku akademickim 1968/69 miał zaplanowany cykl wykładów w Warszawie i badania terenowe w Polsce. Plany te pokrzyżowała nagła śmierć. Zmarł 28 grudnia 1967 roku w Hollis w stanie Nowy Jork. Na warszawskich Powązkach Komunalnych znajduje się jego grób symboliczny.

Spuścizna naukowa Józefa Obrębskiego trafiła - dzięki staraniom wdowy Tamary Obrębskiej oraz profesorów Suli Benet i Joela M. Halperna - do uniwersyteckiego archiwum w Amherst w stanie Massachusetts, gdzie utworzono z niej „Obrebski Collection” (http:// scua.library.umass.edu/umarmot/obrebski-jozef/).

Józef Obrębski jest przykładem wybitnego uczonego, który w myśl utrwalonej o nim opinii nie odniósł sukcesu. Wielu swoich prac nie ukończył, nie opublikował żadnej książki (a tylko 13 artykułów i 17 merytorycznych recenzji oraz polskie przekłady trzech prac Malinowskiego, nie licząc publikacji drobniejszych). Nie stworzył szkoły, nie wychował grona uczniów. Jedynym jego uczniem, który działał po wojnie w środowisku naukowym, był socjolog Stefan Nowakowski15. Choć funkcjonował w kregach akademickich polskich, brytyjskich i amerykańskich, wykładał, był ceniony za wiedze, inteligencję, błyskotliwość, przymioty osobowości, nie zakorzenit się w żadnej instytucji i jego nazwisko nie stało się szeroko znane, a twórczość naukowa nie weszła do kanonu nauk społecznych.

Przyczyny tego stanu rzeczy - i tym samym także nieobecności Obrębskiego w kanonicznych ujęciach historii antropologii i socjologii - były złożone i ich całościowa re-

11 Przekład polski: Obrębski, 2005c.

12 Pierwodruk angielski i przekład polski w: Obrębski, 2006c, $2006 f$.

13 Pierwodruk angielski i przekład polski w: Obrębski, 2006d, 2006e.

14 Pierwodruk angielski: Obrębski, 1969, przekład polski: Obrębski, $2005 e$.

15 Poświęcit on Obrębskiemu, poza okolicznościowymi tekstami in memoriam, artykuł omawiający jego twórczość naukową (zob. Nowakowski, 1992b). 
konstrukcja nie jest już dziś możliwa. Niewątpliwie należałoby wśród nich wskazać okoliczności historyczne, a więc po pierwsze wojnę, okupację i powstanie w Warszawie, kiedy to uległa zniszczeniu gotowa do druku monografia, będąca pokłosiem badań terenowych Obrębskiego wśród górali macedońskich ${ }^{16}$. Po drugie - powojenną zmianę systemu politycznego w Polsce, której konsekwencją dotykającą jego działalności naukowej było między innymi przesunięcie tematów, którymi zajmował się przed wojną, do kategorii zakazanych z powodów politycznych. Kraj, w którym prowadził wcześniej swoje najbardziej ważkie teoretycznie badania - białorusko-ukraińskie Polesie - znalazł się w granicach Związku Radzieckiego i informacja o nim zaczęła podlegać cenzurze politycznej. W efekcie nie ukazało się drukiem ani Polesie archaiczne, ani Pańska szkoła i mużyckie dzieci"17. Maszynopis tej drugiej pracy, datowany "Warszawa 1943”, został przygotowany przez autora do druku w roku 1945. Książka, pod bardziej neutralnym tytułem Szkoła na Polesiu, miała się ukazać jako drugi tom redagowanej przez Chałasińskiego i wydawanej przez „Czytelnik” serii „Prace Polskiego Instytutu Socjologicznego. Studium problemów chłopskich i robotniczych" (tomem pierwszym była Społeczna ge nealogia inteligencji polskiej Józefa Chałasińskiego). Powody wstrzymania tej publikacji mogły być tylko polityczne.

Obrębski opuścił kraj w połowie 1946 roku, w związku z czym ustała jego intensywna działalność badawcza i organizacyjna w środowisku socjologicznym i etnologicz$n^{n}{ }^{18}$. Mimo że był to wyjazd w pełni legalny i że w późniejszych latach jako urzędnik w ONZ reprezentował Polske i przyjeżdżał tu na urlopy, ostatecznie przerodził się on w emigrację (obywatelstwo amerykańskie przyznano mu w 1964 r.). Trzecią przyczyną jest więc emigracja Obrębskiego. Emigracja, która nie przyniosła mu sukcesów w karierze naukowej. Będąc człowiekiem dojrzałym, o habitusie europejskiego intelektualisty, nie zaadaptował się w pełni do wymagań systemu amerykańskiej akademii z jego kryteriami efektywności, w którym funkcjonował przez ostatnie dziewięć lat życia. (To z obserwacji tego systemu wyrosła dekonstruująca m.in. jego mechanizmy opublikowana w 1962 r. Struktura rewolucji naukowych Thomasa Kuhna). Amerykańscy koledzy Obrębskiego z kręgów akademickich postrzegali go jako człowieka marginesu. Zarazem, we wspomnieniach i wypowiedziach z kręgu rodziny i przyjaciół przewijają się motywy jego wewnętrznej niezależności i jednocześnie wyjątkowej skromności; nie był człowiekiem, który chciał i umiał promować samego siebie. Że był jak najdalszy od konformizmu, nie ulega kwestii.

Malinowski sformułował o młodym Józefie Obrębskim opinię następującej treści:

Nie ma żadnej wątpliwości, że należy do najzdolniejszych wśród młodzieży etnologicznej. Jest dobrym pracownikiem, oryginalnym, przenikliwym, efektywnym. Z pewnością ma iskrę geniuszu. Przy tym wszystkim nie jest pewne, czy faktycznie wysunie się na czoło. Z tego, co wiem, ma w papierach co najmniej dwa manuskrypty niemal gotowe do publikacji, które, obawiam się, nigdy nie ujrzą światła dziennego. Skrajny perfekcjonizm; sam cierpię na tę słowiańską chorobę (i wiele innych). Niech Pan będzie w stosunku do Obrębskiego bardzo wyrozumiały. Nie tracę nadziei, że znajdzie się w pierwszym szeregu ${ }^{19}$.

\section{-....}

16 Był to maszynopis książki Macedońska wiara i obrzędy. Socjologiczny opis wierzeń i obrzędów magiczno-religijnych Porecza w serbskiej Macedonii, Warszawa 1944.

17 Publikacja obu tych monografii doszła do skutku dopiero w 2007 roku, w tomie Polesie (zob. Obrębski, 2007e, 2007f)

18 Na temat tej działalności pisałam obszerniej w: Engelking, 2006

19 List Malinowskiego do Dra Kittredge'a z Fundacji Rockefellera, datowany 22.10.1933; Archiwum LSE, tłum. A. E. 
Spleciona z biegiem historii zdarzeniowej biograficzna trajektoria oraz uwarunkowania psychologiczne Obrębskiego, które dostrzegał nie tylko Malinowski, miały wpływ także na to, że po czwarte, nie ukończył on opracowywania syntez badań terenowych prowadzonych na Jamajce (za pieniądze z brytyjskiego grantu). Gdyby opublikował choć jedną z zaawansowanych już monografii, miałby szansę na miejsce w pierwszym szeregu antropologów brytyjskich czy amerykańskich.

Pytając o przyczyny niespełnienia czy też nieobecności Obrębskiego, nie można też tracić z oczu być może najważniejszej z nich: jego wczesnej śmierci. Zmarł mając 62 lata, u progu emerytury, którą zamierzał poświęcić pracy nad materiałami z Macedonii i Polesia. Po to właśnie sprowadził z Warszawy do Nowego Jorku swoje przedwojenne archiwum terenowe. Po śmierci Obrębskiego około 90\% jego prac pozostało w maszynopisach i rękopisach. Studia opublikowane wcześniej po polsku nie były znane badaczom nieczytającym w tym języku. Skromna liczba i ograniczona recepcja publikacji jest oczywistą przyczyną nieznajomości jego dzieła w szerszym kręgu antropologów i socjologów.

Ale nie tylko. Jak dowodzi w zamieszczonym tu artykule Marcin Lubaś, „koncepcje Obrębskiego powstałe w oparciu o badania poleskie zawierały idee prawdziwie przełomowe, uderzające w domyślne założenia ówczesnego myślenia naukowego" (Lubaś, 2019, s. 3). Otwartość i nieszablonowość, charakterystyczne dla jego myślenia, wprowadzały niepokój w obręb obowiązującego paradygmatu naukowego (który zawsze jest modelem selektywnym), prowokowały do rozszczelniania jego ram. Tworzyły warunki do kryzysu, a w konsekwencji - do rewolucji naukowej (by odwołać się do Kuhnowskiej koncepcji cyklicznego rozwoju nauki). Aż do czasu, gdy w naukach społecznych doszły do głosu nowe generacje badaczy, ukształtowane $w$ warunkach przełomu postmodernistycznego, to napięcie między sztywnością paradygmatu a kwestionującymi go koncepcjami Obrębskiego musiało być, ze względu na reguły funkcjonowania „normalnej” nauki, ignorowane. Jak ujmuje to Lubaś,

Myśl taka, chociaż niepokojąca i inspirująca, niełatwo jest przyswajalna w całości. Nie można jej ująć w doktrynę. Koncepcje Obrębskiego przyjmowano powoli, we fragmentach i z niematymi oporami, wpływ jego idei zdaje się bardziej uchwytny jedynie pod warunkiem uwzględnienia długich serii zdarzeń. Dzieło to wpisuje się w osobliwie rozciągnięty w czasie proces, "długą rewolucję", [...] czyli wielogeneracyjny, wieloaspektowy i wcale nie-nieuchronny ciąg przeobrażeń [...] (Lubaś, 2019, s. 4).

Refleksja nad casusem Obrębskiego uprzytamnia także pozajednostkowe - historyczne, systemowe, instytucjonalne - mechanizmy marginalizacji i niespełnień. Wskazuje na relacje władzy w akademii - relacje warunkowane przez społeczne struktury intelektualne, personalne, finansowe, polityczne. Na przenikanie się nauki i polityki, nauki i ideologii. Dlatego w badaniu biografii i dorobku Obrębskiego nie chodzi tylko o niego samego. Chodzi zarazem o krytyczne, czy inaczej antropologiczne, spojrzenie na historię nauki, która nie da się zredukować do historii treści, generowanych w jej polu, do historii abstrahującej od uwarunkowań pozanaukowych.

Bo jak w końcu chcemy opisywać, rozumieć i definiować nauke jako fenomen społeczno-kulturowy? Wszak fakt, że Obrębski nie zrobił kariery naukowej, konceptualizowanej w zachodnich kategoriach sukcesu, nie unieważnia tego, że był wybitnym, niesłychanie twórczym aktorem pola nauki. Jego ustalenia i inspiracje zaczęły wywierać wpływ na to pole na dobrą sprawę dopiero po jego śmierci, co obserwujemy nie tylko w polskiej humanistyce i naukach społecznych. Jednym z przejawów tego zjawiska jest prezentowany tu cykl artykułów. 
Do lektur warszawskich etnologów w latach siedemdziesiątych i osiemdziesiątych XX wieku należał Problem etniczny Polesia i inne artykuły Obrębskiego dotyczące Polesia i etniczności. Było to zasługą Profesor Anny Kutrzeby-Pojnarowej, wychowanki krakowskiego ośrodka etnologicznego, która choć nie znała Obrębskiego osobiście w czasach, gdy był związany ze Studium Słowiańskim UJ, znała i przekazywała żywą legendę o nim. To ona wzięła na siebie zadanie pamiętania o Obrębskim w imieniu środowiska etnologicznego. Pierwsza pisała w latach siedemdziesiątych o jego dorobku i myśli teoretycznej (Kutrzeba-Pojnarowa, 1972, 1977, 1979). Kilkakrotnie podejmowała próby publikacji jego prac, składała propozycje wydawnictwom naukowym. Choć próby te nie przyniosły wówczas rezultatu, to niewątpliwie właśnie dzięki Kutrzebie-Pojnarowej rozpoczął się proces przywracania nauce polskiej i światowej dorobku uczonego i wiedzy o nim.

Do początku XXI wieku badaczom społecznym w Polsce znane były przede wszystkim wspomniane na wstępie cztery artykuły Obrębskiego z 1936 roku (Obrębski, 1936a, 1936b, 1936c, 1936d), będące wykładem jego nowatorskiej, nieesencjalizującej teorii grup etnicznych jako „tworów wyobrażeniowych", ufundowanych na „poczuciu odrębności i świadomości istniejących różnic" (Obrębski, 2005b, s. 157, 2007d, s. 260). Sytuacja zaczęła ulegać zmianie po opublikowaniu przedruków najważniejszych jego artykułów oraz pierwszych prac wydobytych z archiwów: wykładu O metodzie funkcjonalnej Bronisława Malinowskiego (Obrębski, 2004), niewielkiego wyboru pism, pełniącego funkcję zwiastuna serii Studia etnosocjologiczne (Obrębski, 2005a), dwujęzycznego wyboru artykułów w jubileuszowym tomie "Spraw Narodowościowych" w 2006 roku, przede wszystkim zaś tomu Polesie w roku 2007. W efekcie zwłaszcza tej ostatniej publikacji Józef Obrębski jako autor wnikliwych etnosocjologicznych diagnoz wywiedzionych z obserwacji rzeczywistości społecznej wsi poleskiej funkcjonuje od niedawna także jako klasyk w zakresie badań nad prawosławnymi społecznościami chłopskimi w II Rzeczypospolitej, albo inaczej rzecz ujmując, nad wschodniosłowiańskimi mniejszościami narodowymi w państwie polskim, co każe postrzegać go także jako prekursora studiów postkolonialnych.

Ten aspekt poleskiego dorobku Obrębskiego znajduje rozwinięcie we wchodzących w skład prezentowanego cyklu artykułach Piotra Cichorackiego i Pavla Ablamskiego. Obaj autorzy potwierdzają jego obserwacje i analizy, dostarczając im kontekstualizacji w postaci danych z różnego typu źródeł historycznych z epoki, począwszy od wytworzonych przez państwową administrację, skończywszy na dokumentach osobistych. Tym samym, weryfikują je pozytywnie - z jednej strony, przez ugruntowany w wiedzy historycznej wgląd w zachodzące na Polesiu procesy społeczno-polityczne, jak Cichoracki, z drugiej - przez dotyczące jakościowej strony procesu unarodowienia faktograficzne dopełnienia ze źródeł, jak Ablamski. Oba te artykuły unaoczniają, jak głęboko etnosocjologia Polesia w wersji Obrębskiego zakorzeniła się już w kanonie badań nad historią II Rzeczypospolitej.

Zgadzam się ze stwierdzeniem Cichorackiego, że „[P]race socjologiczno-etnograficzne Józefa Obrębskiego poświęcone Polesiu należy dziś uznać za najpełniejszy obraz tamtejszej wsi w okresie międzywojennym" (Cichoracki, 2019, s. 3). W istocie rzeczy udokumentowany przez Obrębskiego obraz jest o wiele bogatszy, bardziej szczegółowy i zniuansowany niż ten, który znamy z dotychczas opublikowanych pism. Jak bowiem wspomniałam wcześniej, źródła wytworzone w terenie podczas ekspedycji poleskiej pozostają nadal w amerykańskim archiwum. Z oczywistych względów nie mogły wejść do tomu Polesie: jest to liczący około 2500 stron zbiór materiałów terenowych samego Ob- 


\section{Józef Obrębski \\ STUDIA ETNOSOCJOLOGICZNE}
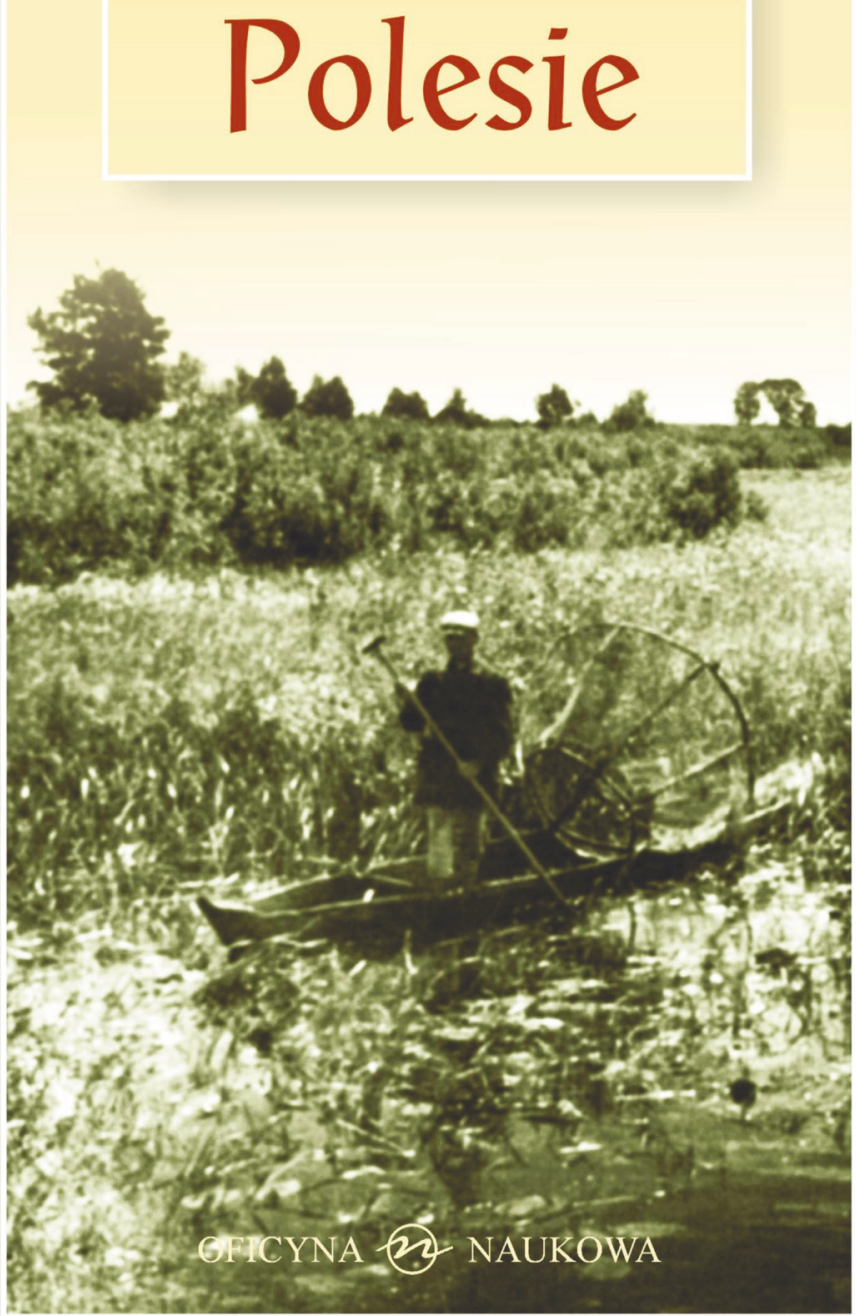

Okładka książki Polesie - pierwszego tomu Studiów etnosocjologicznych Józefa Obrębskiego 
rębskiego i kilkorga jego współpracowników. Notesy i zeszyty, zapełnione dwujęzycznymi notatkami (dialektalnymi poleskimi i polskimi), niejednokrotnie trudno czytelnymi, by mogły służyć szerszemu gronu użytkowników, wymagają nie tylko żmudnej deszyfracji, ale też opracowania naukowego. Co istotne jako komentarz do omawianych artykułów, odzwierciedlają one między innymi te aspekty życia wsi poleskiej, które zdaniem Cichorackiego i Ablamskiego nie zostały przez Obrębskiego wyeksponowane. Znajdujemy w nich mianowicie bogatą dokumentację sympatii do Związku Radzieckiego i scenariusza rewolucyjnego, relacje o brutalnym biciu chłopów przez policjantów i bezwzględnych działaniach sekwestratorów, emocjonalne świadectwa intensywności konfliktu chłopów z leśnikami, a także dużo szczegółowych danych świadczących o zróżnicowaniu terytorialnym Polesia, gdy chodzi o świadomość narodową i aktywność ruchu ukraińskiego, białoruskiego i komunistycznego.

Archiwalne materiały terenowe dają także odpowiedź na kwestie wyłaniające się z zamykającego cykl artykułu Siarhieja Hruntowa, poświęconego Żydom w pismach poleskich Obrębskiego. Jak pamiętamy, w dyskusji po referacie „Dzisiejsi ludzie Polesia”, odpowiadając na głosy, iż w swojej syntezie pominął Żydów, Obrębski argumentował, że było to konsekwencją ram teoretycznych, jakie wyznaczył dla swoich badań. „[P]ierwsze miejsce [...]" - mówił wówczas - „zajęła analiza stosunku Poleszuków do pokrewnych im etnicznie grup narodowych, a więc w pierwszym rzędzie Polaków, dalej Ukraińców, Białorusinów i Rosjan. Grupy obce i odległe, takie np. jak Niemcy czy Żydzi, nie mogły wchodzić tu w gre w tym samym stopniu" (Obrębski, 2007c, s. 328). Choć Żydzi i relacje polesko-żydowskie $w$ tamtym momencie interesowały go badawczo $w$ mniejszym stopniu, nie znaczy to bynajmniej, że nie doceniał społecznej, politycznej i symbolicznej wagi tej problematyki. W żywej paginie w jego notesach terenowych, którą nanosił na notatki czerwoną kredką po angielsku, relatywnie często powtarzają się słowa klucze "Jews" i "Antisemitism". Sądzę, że w planowanej książce o współczesnej wsi poleskiej Obrębski zamierzał potraktować temat żydowski bardziej analitycznie, niż uczynił to w Polesiu archaicznym. Być może zarówno przedstawiona w monografii o "czasach ojców i dziadów" struktura społeczna oparta na trójkącie panowie-chłopi-Żydzi, jak i mające wydźwięk antysemicki cytaty z Kraszewskiego stanowiłyby koncepcyjny punkt odniesienia w pracy o "czasach synów”, którą znamy jedynie z fragmentarycznych notatek i konspektów (Obrębski, 2007b).

Hruntou słusznie podkreśla, że ograniczenia przedstawionego przez Obrębskiego wizerunku poleskich Żydów - grupy społecznej i narodowej, dodajmy, która stanowiła liczebną większość w miastach i miasteczkach Polesia i której przedstawiciele żyli w każdej większej wsi - wynikają nie tylko z przyjętych przez niego ram teoretycznych, lecz także z wybranych do analizy tych a nie innych XIX-wiecznych źródeł. Mając na uwadze fakt, że nad Polesiem archaicznym autor pracował w czasie okupacji niemieckiej, kiedy dostęp do warszawskich zasobów bibliotecznych był poważnie utrudniony, musimy jednocześnie stale pamiętać, że prace Obrębskiego w wersji, którą znamy z pośmiertnych publikacji, nie były poddane jego autoryzacji. Ich immanentne ograniczenie polega na tym, że mają charakter do pewnego stopnia roboczy, warsztatowy. Przy czym jest to zarazem cecha sprzyjająca ich otwartości i dialogiczności, jeden z czynników, który sprawia, że od Obrębskiego tak wiele oczekujemy.

Prezentowany w niniejszym tomie „Spraw Narodowościowych" cykl artykułów skupionych wokół zagadnień etnosocjologii Polesia w ujęciu Obrębskiego świadczy o żywotności procesu rozpoczętego tekstem Pozycja Józefa Obrębskiego w etnografii polskiej Kutrzeby-Pojnarowej (Kutrzeba-Pojnarowa, 1972). Cykl ten powstał w efekcie inspiracji 
czerpanych z jego dzieła i życia przez przedstawicieli różnych dyscyplin - socjologa, dwoje etnologów i dwóch historyków. Ta istotna merytorycznie interdyscyplinarność perspektyw, możliwa dzięki funkcjonowaniu w obiegu naukowym stopniowo coraz większej liczby prac uczonego, jak również tekstów traktujących o jego dorobku i biografii, wpisuje się znacząco we współczesną tym razem historię recepcji Obrębskiego. Recepcji, jak widać, twórczej, i ciągle na nowo generującej naukową dyskusję.

\section{BIBLIOGRAFIA}

Alunina, I. (2006). Białoruskie badania Polesia przed Józefem Obrębskim. Sprawy Narodowościowe, 2006(29), 63-71.

Armon, W. (1978). Obrębski Józef. W Polski Słownik Biograficzny (T. 23/3 (98), ss. 461463). Wrocław: Polska Akademia Nauk.

Bahdanovich, I. Ė., \& Svistunowa, M. I. (Red.). (2018). Belaruska-pol'skiia moŭnyia, litaraturnyia, histarychnyia i kul'turnyia suviazi: Da 220-hoddzia z dnia naradzhénnia Adama Mitskevicha. Minsk: BDU. (Belarusika-Albaruthenica, 38). Pobrano z http://elib.bsu.by/ handle/123456789/214781? offset=20

Cichoracki, P. (2019). Wieś poleska doby przemian lat trzydziestych XX wieku w ujęciu Józefa Obrębskiego. Sprawy Narodowościowe, 2019(51), 1-9. https://doi.org/10.11649/ sn.1866

Czarniakiewicz, I. (2006). Wkład Józefa Obrębskiego w badania nad poleską rodziną. Sprawy Narodowościowe, 2006(29), 73-80.

Engelking, A. (2001). Poleska ekspedycja etnosocjologiczna Józefa Obrębskiego w latach 1934-1937: Organizacja. Metody badań. Problematyka. Uczestnicy. Etnografia Polska, 45(1-2), 23-45.

Engelking, A. (2006). Józef Obrębski - etnolog i socjolog warszawski. Sprawy Narodowościowe, 2006(29), 91-106.

Engelking, A. (2007a). Józef Obrębski (1905-1967). W E. Fryś-Pietraszkowa \& A. Spiss (Red.), Etnografowie i ludoznawcy polscy: Sylwetki, szkice biograficzne (T. 2, ss. 226233). Wrocław: Polskie Towarzystwo Ludoznawcze.

Engelking, A. (2007b). Polesie Józefa Obrębskiego. W J. Obrębski, Studia etnosocjologiczne: T. 1. Polesie (A. Engelking, Red.) (ss. 9-32). Warszawa: Oficyna Naukowa.

Engelking, A. (2018). Macedońskie Trobriandy. Józef Obrębski i pierwsze badania wsi europejskiej w paradygmacie funkcjonalizmu. Lud, 102, 185-210. https://doi. org/10.12775/lud102.2018.06

Engelking, A. (2019). Nauka na usługach polityki? Przypadek Józefa Obrębskiego. Sprawy Narodowościowe, 2019(51), 1-24. https://doi.org/10.11649/sn.1863

Kutrzeba-Pojnarowa, A. (1972). Pozycja Józefa Obrębskiego w etnografii polskiej. Etnografia Polska, 16(1), 215-219.

Kutrzeba-Pojnarowa, A. (1977). Józef Obrębski. W A. Kutrzeba-Pojnarowa, Kultura ludowa i jej badacze: Mit i rzeczywistość (ss. 111-120). Warszawa: Ludowa Spółdzielnia Wydawnicza.

Kutrzeba-Pojnarowa, A. (1979). Wkład Józefa Obrębskiego w badanie procesów etnicznych. Etnografia Polska, 23(2), 72-82. 
Lubaś, M. (2019). Dokument myśli otwartej. Studia poleskie Józefa Obrębskiego a rozważania o grupach etnicznych i stosunkach narodowościowych w polskiej etnologii i socjologii. Sprawy Narodowościowe, 2019(51), 1-20. https://doi.org/10.11649/sn.1895

Nowakowski, S. (1992a). Druga wojna światowa i jej społeczno-kulturowe odbicie w społeczności socjologicznej (wspomnienia i luźne refleksje). W S. Nowakowski, Sylwetki polskich socjologów (ss. 235-260). Warszawa: IFiS PAN.

Nowakowski, S. (1992b). Józef Obrębski - socjolog niedoceniony. W S. Nowakowski, Sylwetki polskich socjologów (ss. 151-177). Warszawa: IFiS PAN.

Obrębski, J. (1929). Rolnictwo ludowe wschodniej części półwyspu Bałkańskiego. Cz. 1. Lud Stowiański, 1(1), B10-B54.

Obrębski, J. (1930). Rolnictwo ludowe wschodniej części półwyspu Bałkańskiego. Cz. 2. Lud Stowiański, 1(2), B147-B187.

Obrębski, J. (1931a). Rolnictwo ludowe wschodniej części półwyspu Bałkańskiego. Cz. 3. Lud Stowiański, 2(1), B9-B27.

Obrębski, J. (1931b). Rolnictwo ludowe wschodniej części półwyspu Bałkańskiego. Cz. 4. Lud Stowiański, 2(2), B133-B148.

Obrębski, J. (1934). Czarna magja w Macedonii. Kurier Literacko-Naukowy, 111, VI-VIII.

Obrębski, J. (1936a). Dzisiejsi ludzie Polesia. Przegląd Socjologiczny, 4(3-4), 414-446.

Obrębski, J. (1936b). Problem etniczny Polesia. Sprawy Narodowościowe, 10(1-2), 1-23.

Obrębski, J. (1936c). Problem grup etnicznych w etnologii i jego socjologiczne ujęcie. Przegląd Socjologiczny, 4(1-2), 177-195.

Obrębski, J. (1936d). Statyczne i dynamiczne podejście w badaniach narodowościowych. Sprawy Narodowościowe, 10(6), 585-600.

Obrębski, J. (1936e). System religijny ludu macedońskiego. Cz. 1. Kurier Literacko-Naukowy, 1936(24), XIII-XIV.

Obrębski, J. (1936f). System religijny ludu macedońskiego. Cz. 2. Kurier Literacko-NaukoWy, 1936(26), XI-XII.

Obrębski, J. (1936g). System religijny ludu macedońskiego. Cz. 3. Kurier Literacko-Naukowy, 1936(28), XI-XIII.

Obrębski, J. (1936h). System religijny ludu macedońskiego. Cz. 4. Kurier Literacko-NaukoWy, 1936(29), XI-XII.

Obrębski, J. (1936i). System religijny ludu macedońskiego. Cz. 5. Kurier Literacko-Naukowy, 1936(30), XIII.

Obrębski, J. (1951). The sociology of rising nations. Unesco International Social Science Bulletin, 3(2), 237-243.

Obrębski, J. (1969). Ritual and social structure in a Macedonian village (B. Halpern, Red.). Boston, MA: Boston University, American Association for the Advancement of Slavic Studies.

Obrębski, J. (1976). The changing peasantry of Eastern Europe (B. Halpern \& J. Halpern, Red.). Cambridge, MA: Schenkman Publishing Company.

Obrębski, J. (2004). O metodzie funkcjonalnej Bronisława Malinowskiego (A. Engelking, Red.). Studia Socjologiczne, 173(2), 35-63.

Obrębski, J. (2005a). Dzisiejsi ludzie Polesia i inne eseje (A. Engelking, Red.). Warszawa: IFiS PAN.

Obrębski, J. (2005b). Problem grup i zróżnicowań etnicznych w etnologii i jego socjologiczne ujęcie. W J. Obrębski, Dzisiejsi ludzie Polesia i inne eseje (A. Engelking, Red.) (ss. 153-172). Warszawa: IFiS PAN. 
Obrębski, J. (2005c). Socjologia powstających narodów. W J. Obrębski, Dzisiejsi ludzie Polesia i inne eseje (A. Engelking, Red.) (ss. 195-207). Warszawa: IFiS PAN.

Obrębski, J. (2005d). Statyczne i dynamiczne podejście w badaniach narodowościowych. W J. Obrębski, Dzisiejsi ludzie Polesia i inne eseje (A. Engelking, Red.) (ss. 173-193). Warszawa: IFiS PAN.

Obrębski, J. (2005e). Struktura społeczna i rytuał we wsi macedońskiej (A. Engelking, Tłum.). W J. Obrębski, Dzisiejsi ludzie Polesia i inne eseje (A. Engelking, Red.) (ss. 71-88). Warszawa: IFiS PAN.

Obrębski, J. (2006a). Czarna magia w Macedonii. Sprawy Narodowościowe, 2006(29), 147-151.

Obrębski, J. (2006b). Legitimacy and illegitimacy in Jamaica: A non-deviant case. Sprawy Narodowościowe, 2006(29), 296-304.

Obrębski, J. (2006c). Peasant family and national society in Jamaica. Sprawy Narodowościowe, 2006(29), 305-311.

Obrębski, J. (2006d). Powstawanie narodów: Ujęcie antropologiczne. (A. Engelking, Tłum.). Sprawy Narodowościowe, 2006(29), 271-278.

Obrębski, J. (2006e). Rising nations from an anthropological perspective. Sprawy Narodowościowe, 2006(29), 312-320.

Obrębski, J. (2006f). Rodzina chłopska a społeczeństwo narodowe Jamajki (J. Serwański, Tłum.). Sprawy Narodowościowe, 2006(29), 263-270.

Obrębski, J. (2006g). System religijny ludu macedońskiego. Sprawy Narodowościowe, 2006(29), 152-167.

Obrębski, J. (2006h). Ślubne i nieślubne pochodzenie na Jamajce - przypadek zgodny z normą (J. Serwański, Tłum.). Sprawy Narodowościowe, 2006(29), 253-262.

Obrębski, J. (2007a). Dzisiejsi ludzie Polesia. W J. Obrębski, Studia etnosocjologiczne: T. 1. Polesie (A. Engelking, Red.) (T. 1, ss. 276-318). Warszawa: Oficyna Naukowa.

Obrębski, J. (2007b). [Dzisiejsza wieś poleska]. W J. Obrębski, Studia etnosocjologiczne: T. 1. Polesie (A. Engelking, Red.) (ss. 448-549). Warszawa: Oficyna Naukowa.

Obrębski, J. (2007c). Dyskusja po referacie Józefa Obrębskiego "Dzisiejsi ludzie Polesia”. W J. Obrębski, Studia etnosocjologiczne: T. 1. Polesie (A. Engelking, Red.) (ss. 319334). Warszawa: Oficyna Naukowa.

Obrębski, J. (2007d). Lud bez ojczyzny. W J. Obrębski, Studia etnosocjologiczne: T. 1. Polesie (A. Engelking, Red.) (ss. 186-275). Warszawa: Oficyna Naukowa.

Obrębski, J. (2007e). Pańska szkoła i mużyckie dzieci. W J. Obrębski, Studia etnosocjologiczne: T. 1. Polesie (A. Engelking, Red.) (ss. 335-434). Warszawa: Oficyna Naukowa.

Obrębski, J. (2007f). Polesie archaiczne. W J. Obrębski, Studia etnosocjologiczne: T. 1. Polesie (A. Engelking, Red.) (ss. 33-185). Warszawa: Oficyna Naukowa.

Obrębski, J. (2007g). Studia etnosocjologiczne: T. 1. Polesie (A. Engelking, Red.). Warszawa: Oficyna Naukowa.

Posern-Zieliński, A. (2006). Józef Obrębski i antropologia Karaibów. Sprawy Narodowościowe, 2006(29), 123-145.

Risteski, L. S. (2011). Josef Obrebski's anthropological research on Macedonia. Etnoantropoloszki problemi, 6(4), 837-858. https://doi.org/10.21301/eap.v6i4.1

Wincławski, W. (2007). Obrębski Józef. W W. Wincławski, Słownik biograficzny socjologii polskiej (T. 3, ss. 47-52). Toruń: Wydawnictwo Uniwersytetu Mikołaja Kopernika. 